\title{
Microbial production of glycyrrhetic acid 3-0-mono- $\beta$-D-glucuronide from glycyrrhizin by Aspergillus terreus
}

\author{
Amin, H. A. ${ }^{1 \star}$, El- Menoufy, H. A. ${ }^{1}$, El-Mehalawy, A. A. ${ }^{2}$ and Mostafa, E. E. ${ }^{1}$ \\ ${ }^{1}$ Natural and Microbial Products Chemistry Department, National Research Center, Dokki, Cairo, Egypt. \\ ${ }^{2}$ Microbiology Department, Faculty of Science, Ain Shams University. \\ E-mail: halaamin2007@yahoo.com
}

Received 28 September 2009; received in revised form 27 March 2010; accepted 30 March 2010

\begin{abstract}
Among seven fungi (three Aspergilli and four Penicilli) have been screened for production of glycyrrhetic acid 3-O-mono$\beta$-D-glucuronide (GAMG) from glycyrrhizin (GL), Aspergillus terreus was found to be the most potent GAMG producer. This strain was capable of expressing two intracellular $\beta$-D-glucuronidase forms, one responsible for partial hydrolysis of GL to GAMG and the other one for hydrolysis of GL to glycyrrhetic acid (GA). The highest yield of GAMG was achieved when the reaction mixture was incubated at $\mathrm{pH} 6$ at $40{ }^{\circ} \mathrm{C}$ for $1 \mathrm{~h}$ using $\mathrm{GL}(0.1 \%, \mathrm{w} / \mathrm{v})$ as a substrate. The maximum hydrolytic activity for production of GAMG $(396 \mathrm{U} / \mathrm{mL})$ was obtained using production medium composed of $(\mathrm{g} \%$, w/v): corn steep liquor 2.5, soybean flour 3.5 , glucose 0.5 and $\mathrm{CaCO}_{3} 0.5 ; \mathrm{pH} 6.0$. The medium was inoculated with $15 \%(\mathrm{v} / \mathrm{v})$ inoculum and incubated at $27^{\circ} \mathrm{C}$ for 3 days. Under these optimal conditions, GAMG yield became about 2 times higher than GA yield and the cells bioconversion efficiency increased from 24.6 to $78.3 \%$.
\end{abstract}

Keywords: $\beta$-Glucuronidase, Aspergillus terreus, Glycyrrhizin, Glycyrrhetic acid 3-O- mono - $\beta$-D- glucuronide

\section{INTRODUCTION}

Glycyrrhizin (GL) is a well known pharmacologically active sweet saponin of licorice roots (Glycyrrhiza glabra) and is composed of the aglycone, $\beta$-glycyrrhetic acid (GA), and two molecules of D-glucuronic acid attached to the C-3 atom of the aglycon moiety (Muro et al., 1986). Hydrolyzed one distal glucuronic acid, GL is transformed into glycyrrhetic acid monoglucuronide (GAMG) which has several advantages over GL (Mizutani et al., 1998; Lu et al., 2008). As a sweetener with high sweetness and low calorie; sweetness is 941 times of the sucrose, and 5 times of the GL (Akao et al., 1991 ; Kuramoto et al., 1994). In addition, pharmacological researches shown that $L_{50}$ of GAMG is $5000 \mathrm{mg} / \mathrm{kg}$ while that of $\mathrm{GL}$ was $805 \mathrm{mg} / \mathrm{kg}$ (Feng et al., 2006), which means that GAMG has higher safety than GL. Also, it exhibits the similar (or stronger) anti-allergic (Park et al., 2004), anti-inflammatory (Akao et al., 1992), anti-cancer (Mizutani et al., 1998), antianaphylaxis (Park et al., 2004) and anti-virus (Ito et al., 1988). It should be noteworthy that GL is hardly soluble in water, and generally used as a form of water soluble salt, while GAMG itself is readily soluble in water. As for these facts, GAMG is expected to be a potential substitute of $G L$ in wider applications.

Biocatalysis and biotransformation have many advantages, such as high substrate specificity and mild reaction conditions (Feng et al., 2006). GAMG could be produced from $\mathrm{GL}$ by lysosomal $\beta$-D-glucuronidase of animal livers (Akao et al., 1991) and by many $\beta$-Dglucuronidases derived from human intestinal bacteria
(Kim et al., 1999; Akao, 2000; 2001) but with low enzyme specialty. However, only Cryptococcus magnus MG $27^{+}$ had high selectivity to produce GAMG in industrial scale (Kuramoto et al., 1994). Scarce previous studies have been found on bioconversion of Gl to GAMG by fungi. Recently, Feng et al. (2006) reported that Penicillium sp. Li-3 $\beta$-glucuronidase hydrolyzed GL to GAMG directly.

Here, we concerned with studying the production of GAMG from GL by fungi. For this purpose, we described the screening for a highly directed biosynthesizing GAMG strain and optimization of the reaction conditions as well as the enzyme production conditions.

\section{MATERIALS AND METHODS}

\section{Microorganisms}

The different microorganisms used in this work (Table 1) were kindly obtained from the Center of Cultures of Natural and Microbial Product Chemistry Department, National Research Center, Cairo, Egypt. These are: Aspergillus tamarii , A. terreus, Penicillium auranticum, $P$. cyclopium, $P$. frangnatum and $P$. waksmani, except Aspergillus niger NRRL 595 was from collection of North Regional Research Laboratory USA (NRRL).

\section{Chemicals}

GL monoamonium salt was purchased from Sigma Chemical Co. (USA). GA and GAMG were from Maruzen 
Pharmaceuticals Co. Ltd. (Japan). All other chemicals were of analytical reagent grade.

\section{Fermentation media $(g \%, w / v)$}

Medium I: GL, 1; glucose, 1; corn steep liquor, 0.8; pH 5.7 (Kuramoto et al., 1994).

Medium II: Malt extract, 2; yeast extract, 0.4, pH 5.3 (Amin, 2005).

Medium III: Soybean flour, 2.5; corn steep liquor, 2.5 $\mathrm{CaCO}_{3}, 0.5 ; \mathrm{pH}$, modified Muro et al. (1986) medium.

Medium IV: Glycerol, 1; peptone, 0.5; meat extract, 0.3 ; yeast extract, 0.3; $\mathrm{K}_{2} \mathrm{HPO}_{4}$., 0.5; pH 7.4 (Sakano and Ohshima, 1986a).

Medium V: Glucose, 2; peptone, 0.5; meat extract, 0.3; dry yeast, $0.3 ; \mathrm{NaCl}, 0.5 ; \mathrm{CaCO}_{3}, 0.3 ; \mathrm{pH} 7$ (Sakano and Ohshima, 1986b).

Medium VI: Glycerol, 0.5 ; glucose, 0.5 ; peptone, 0.5 ; yeast extract, 0.3 ; meat extract, $0.3 ; \mathrm{KH}_{2} \mathrm{PO}_{4}, 0.75 ; \mathrm{pH} 5.6$ (El-Menoufy, 1988).

\section{Conditions of TLC}

Thin layer chromatography (TLC) was performed on silica gel plates (Fluka, silica gel 60F-254, layer thickness 0.2 $\mathrm{mm}$ ) using the following solvent systems:

A- Chloroform - Petroleum ether - acetic acid (6:6:1, v/v).

B- Acetic acid - n-butanol - 1, 2-dichloroethane - water $(4: 1: 4: 1, v / v)$.

\section{Cultivation of fungal strains}

The organisms were pre-cultured in medium II composed of $(\mathrm{g} \%$; w/v) malt extract, 2 ; yeast extract, $0.4, \mathrm{pH} 5.3$ and were incubated for $72 \mathrm{~h}$ at $27^{\circ} \mathrm{C}$ on a rotary shaker at 150 $\mathrm{rpm}$. Unless otherwise stated, these inocula $(5 \mathrm{~mL})$ were transferred to shaker flasks containing $100 \mathrm{~mL}$ of medium III composed of ( $\mathrm{g} \%$, w/v) soybean flour, 2.5; corn steep liquor, 2.5; $\mathrm{CaCO}_{3}, 0.5 ; \mathrm{pH} 6$, which were further cultured under the same conditions. Then, the enzyme activities of supernatant and cells from each fermentation were detected, respectively, in the whole fermentation process.

\section{Enzyme source}

After cultivation, the mycelia were harvested by filtration and washed with $1 \mathrm{M}$ acetate buffer $\mathrm{pH} 5$. The blotted dry mycelia were then ground with approximately twice its weight of washed cold sand in a cold mortar according to the method presented by Sebald et al. (1979). The cell content was extracted with cold $1 \mathrm{M}$ acetate buffer $\mathrm{pH} 5$. Thereafter, the slurry obtained was centrifuged at 5500 rpm for 15 min using "Janetzki $\mathrm{K}_{75}$ Model-centrifuge". The supernatant formed was used as the crude endocellular enzyme preparation "cell free extract".

\section{Assay of $\beta$-D-glucuronidase hydrolytic activity}

Unless otherwise stated, $1 \mathrm{~mL}$ of enzyme solution (supernatant or cell extract) was incubated with $1 \mathrm{~mL}$ of
GL monoamonium salt $(0.2 \%$, w/v) in $1 \mathrm{M}$ acetate buffer $\left(\mathrm{pH} \mathrm{5)}\right.$ for $2 \mathrm{~h}$ at $40{ }^{\circ} \mathrm{C}$. Then, the reaction mixture containing the products were acidified by the addition of $50 \mu \mathrm{L}$ of $1 \mathrm{M} \mathrm{HCl}$, and extracted twice with $2 \mathrm{~mL}$ ethyl acetate. The amounts of GL, GAMG and GA in the ethyl acetate layer were determined. One unit $(U)$ enzyme activity of $\beta$-D-glucuronidase was defined as the amount of enzyme that capable of converting GL to $1 \mu \mathrm{g}$ GAMG or GA per hour under certain condition.

\section{Enzyme activity (E.A):}

\section{E.A $(\mathrm{U} / \mathrm{mL})=\mu \mathrm{g}$ GAMG $/ \mathrm{mL}$ h or $\mu \mathrm{g} \mathrm{GA} / \mathrm{mL} / \mathrm{h}$}

\section{Total enzyme activity (T.E.A):}

T.E.A $(\mathrm{U})=$ Activity $(\mathrm{U} / \mathrm{mL}) \times$ Volume $(\mathrm{mL})$

\section{Determination of GAMG and GA}

The ethyl acetate solution (containing the transformation products) was concentrated to a small volume and mounted on TLC plate. The plate was first chromatographed for GA with solvent system $A$ and secondly for GL and GAMG with solvent system B. GA and GAMG were detected on TLC plates under ultraviolet (UV) light. These compounds were quantitatively analyzed with TLC-scanner $\left(\lambda_{\mathrm{s}}=250 \mathrm{~nm}, \lambda_{\mathrm{r}}=400 \mathrm{~nm}\right)$ by using calibration lines obtained with authentic samples (Kim et al., 1999).

\section{Total bioconversion efficiency (T.B.E)}

$$
\begin{aligned}
\text { T.B.E }(\%)= & \text { GAMG yield }(\%)+\text { GA yield }(\%) \\
\text { GAMG concentration } & \text { GAMield }(\%)= \\
\text { GAMG concentration } & \text { GL }
\end{aligned}
$$

1.3: Factor of conversion of GAMG to $\mathrm{GL}$ on molecular base.

$$
\text { GA yield (\%) = } \frac{\text { GA concentration }}{- \text { GL concentration }} \times 1.76 \times 100
$$

1.76: Factor of conversion of GA to GL on molecular base.

\section{Statistical analysis}

All the experiments were performed in triplicate, and the values expressed as the means of duplicate measurements of three independent samples. Data were analyzed by one-way analysis of variance (ANOVA) using MedCalc Software-version 11.2. The least significant differences at confidence level of $5 \%$ (LSD .05) and $1 \%$ (LSD .01) were calculated to compare the influence of different treatments on the enzyme activity. 


\section{RESULTS AND DISCUSSION}

\section{Screening of microorganisms for production of GAMG from GL}

Seven fungal strains (3 Aspergilli and 4 Penicilli) were screened to select the strain which can biosynthesize GAMG directly from GL with high yield. Table 1 shows that there were two kinds of productions, GAMG and GA. While two strains (A.niger and P.auranticum) failed to perform the desired reaction, the other experimental organisms could perform the desired reaction. A. terreus proved to be the most potent microorganism that could hydrolyze GL leading to formation of promising amounts of GAMG and the total enzyme activity was much higher in the cell than supernatant (3747 and $170 \mathrm{U}$, respectively). Thus, this $\beta$-D-glucuronidase was mainly intracellular enzyme. Feng et al. (2006) reported that GL was hydrolyzed directly into GAMG by an intracellular $\beta$ D-glucuronidase enzyme from Penicillium sp. Li-3 with high production. However, Penicillium frangnatum was considered to be in the second place in the production of GAMG but the responsible enzyme is mainly extracellular.

With respect to GA production, all the tested strains have the ability to produce GA (Table 1) and Aspergillus strains expressed higher enzymatic activity than Penicillium strains. The maximum $\beta$-D-glucuronidase activity (7192 U) was detected in the supernatant of $A$. niger, i.e this $\beta$-glucuronidase is mainly extracellular enzyme. This also was reported by Muro et al. (1986).

The other tested Aspergillus strains showed different behavior, the enzyme activity for production of GA is almost equal in the supernatant and cell in case of $A$. tamarii, while it is mainly intracellular in case of A. terreus.

\section{Optimization of the reaction conditions}

After the selection of $A$. terreus to be our experimental organism for GAMG production, an optimization for the reaction conditions was undergone in the following experiments to direct the hydrolyzing activity towards the production of GAMG and minimizing GA production.

The reaction mixture was incubated at various time intervals while fixing the other conditions. Table 2 shows that by increasing the incubation time of the assay mixture the yield of GAMG was decreased and that of GA was increased. The optimum incubation times for $G A$ and GAMG production were at 1 and $3 \mathrm{~h}$, respectively. So, the assay mixture was incubated for $1 \mathrm{~h}$ in the following experiments.

$\mathrm{pH}$ is one of the most important factors influencing the side groups of the amino acid dissociations in the protein structure (Ortega et al., 2009). Figure 2 shows that good enzyme activities were maintained within $\mathrm{pH}$ range of 5-6 of the reaction. The optimum $\mathrm{pH}$ values for production of GAMG and GA were at $\mathrm{pH} 6$ and 5, respectively. So, $\mathrm{pH}$ of 6 was chosen in the assay mixture. It was also noticed that the $\beta$-D-glucuronidase activities were very sensitive to the reaction $\mathrm{pH}$ and markedly retarded when $\mathrm{pH}$ is less than 5 or beyond 6 . This can be explained by the fact that, the substrate, GL is weak tribasic acid and the variation of the degree of ionization of carboxyl group with $\mathrm{pH}$ affects its binding to enzyme molecule (Lu et al., 2006).

The effect of temperature on $\beta$-D-glucuronidase activity was determined in the temperature range of 25-55 ${ }^{\circ} \mathrm{C}$. As given in Figure 3 the optimum temperature for production of both GAMG and GA was at temperature of $40{ }^{\circ} \mathrm{C}$. Moreover, the enzyme activities were gradually declined at temperatures beyond $40{ }^{\circ} \mathrm{C}$. This occurs changes, this supplies enough energy to break some of the intermolecular attractions between polar groups as well as the hydrophilic forces between non polar groups within the protein structure. When these forces are disturbed and changed, this causes a change in the secondary and tertiary levels of protein structure, and the active site is altered in its conformation beyond its ability to accommodate the substrate molecules it was intended to catalyze (Lu et al., 2006).

Table 1: Glycyrrhizin hydrolysis activities by different fungi

\begin{tabular}{lcccc}
\hline \multirow{2}{*}{ Fungi } & \multicolumn{2}{c}{$\begin{array}{c}\text { Supernatant } \\
\text { Total enzyme activity (U) }\end{array}$} & \multicolumn{2}{c}{ Cell extract } \\
& GAMG & GA & GAMG & GA \\
\cline { 2 - 5 } & 0 & 7192 & 0 & 3620 \\
\hline Aspergillus niger NRRL595 & 52 & 4808 & 50 & 3442 \\
A. tamarii & 170 & 914 & 3747 & 4225 \\
A. terreus & 0 & 100 & 0 & 0 \\
Penicillium auranticum & 80 & 818 & 32 & 308 \\
P. cyclopium & 1339 & 1492 & 337 & 2757 \\
P. frangnatum & 0 & 1469 & 0 & 176 \\
P. waksmani & & & 0 \\
\hline
\end{tabular}

The volume of filtrate was $65 \mathrm{~mL}$ and that of cell extract (see Materials and Methods) was $25 \mathrm{~mL}$. The $\beta$-glucuronidase activity was assayed by the standard assay method. Values are the average of three independent experiments and the maximal mean deviation is $\pm 7 \%$. ANOVA test at $p \leq 0.001$ highly significant, $\leq 0.05$ significant. 
Different concentrations of $\mathrm{GL}(0.5-4 \mathrm{mg} / \mathrm{mL})$ in the reaction mixture were used. The results given in Table 3 show that the enzyme activities for production of GAMG and GA increased with the increase of the substrate supplemented to the reaction mixture up to $2 \mathrm{mg} / \mathrm{mL}$. There was a subsequent reduction in enzyme activities and the bioconversion efficiencies upon increasing GL concentration up to $4 \mathrm{mg} / \mathrm{mL}$. This indicates that the enzyme is inhibited by the substrate at levels above 2 $\mathrm{mg} / \mathrm{mL}$. This effect of substrate was also described by $\mathrm{Lu}$ et al. (2006) for inhibition of $\beta$-D-glucuronidase from the domestic duck liver by increasing GL concentration up to $60 \mathrm{mM}$. On the other hand, the maximum total bioconversion efficiency was attained using $0.5 \mathrm{mg} \mathrm{GL} / \mathrm{mL}$. The highest yield of GAMG and GA were attained at 1 and $0.5 \mathrm{mg} \mathrm{GL} / \mathrm{mL}$, respectively. Therefore, the concentration of $1 \mathrm{mg} \mathrm{GL}$ was used in the assay mixture.

The previously mentioned results suggest that the maximum yield of GAMG $(25.5 \%)$ was obtained when the reaction mixture was incubated for $1 \mathrm{~h}$ at $40{ }^{\circ} \mathrm{C}$ and the $\mathrm{pH}$ was adjusted at $\mathrm{pH} 6$ using $1 \mathrm{mg} \mathrm{GL} / \mathrm{mL}$ tris-maleate buffer (1 M).

\section{Optimization of the cultivation conditions}

Both enzyme formation and activity are highly influenced by the environmental conditions including medium composition (kind and concentration of nutrients), temperature, $\mathrm{pH}$, inoculum size and the incubation period. Optimization for these conditions was carried to determine the most suitable conditions for $\beta$-D-glucuronidase production

\section{Optimization of the enzyme production medium}

Among six nutritive media (I-VI) differing in the nature and lor concentration of some constituents, medium I supported the strongest activity (data not shown). Also, medium III led to fairly strong activity. From the economic view point, medium III was used for the cultivation because soybean flour is much cheaper than GL as carbon source and readily available in good amounts in our country. It is noteworthy to mention that, the other tested media were not effective for production of GAMG or $\mathrm{GA}$. These media were characterized by the presence of carbon sources other than GL or soybean. Therefore, the enzyme expressed by $A$. terreus is a kind of inducing enzyme, which repressed by other carbon sources and could not be expressed by $A$. terreus. The strong enzyme activity recorded in medium III containing soybean may be attributed to the presence of soyasaponins which are closed in their structure to GL. During the expressing of the target enzyme, carbon catabolite repression existed, so only GL or soybean was the elicitor as well as the sole carbon source.

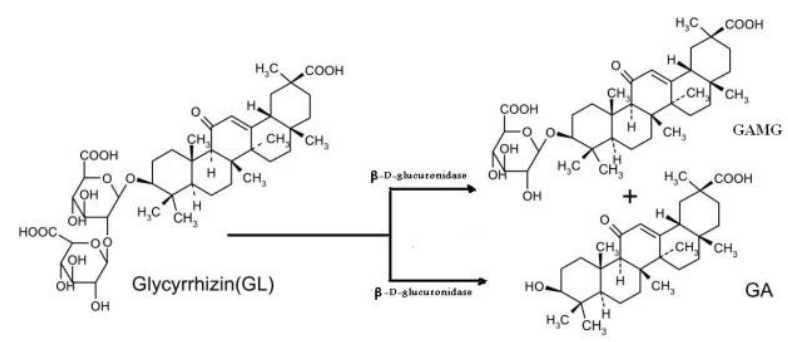

Figure 1: Enzymatic hydrolysis of GL by Aspergillus terreus

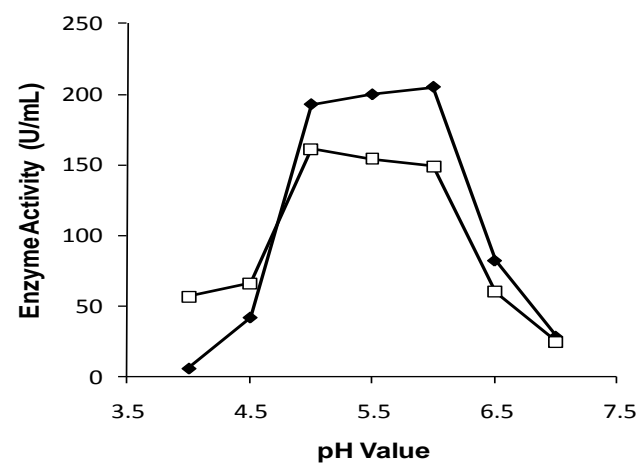

Figure 2: Effect of $\mathrm{pH}$ on $\beta-\mathrm{D}$-glucuronidase activity. The effect of $\mathrm{pH}$ on $\beta$-D-glucuronidase activity was studied using two buffer solutions, $1 \mathrm{M}$ acetate buffer (4-5.5) and $1 \mathrm{M}$ Tris-maleate buffer (67). The reaction mixture was incubated for $1 \mathrm{~h}$ at $40^{\circ} \mathrm{C}$. Values of GAMG ( $\bullet$ ) and GA (口) are the average of three independent experiments and the maximal mean deviation is $\pm 5 \%$

Table 2: Effect of reaction time

\begin{tabular}{|c|c|c|c|c|c|c|c|}
\hline \multirow{2}{*}{$\begin{array}{l}\text { Time } \\
\text { (h) }\end{array}$} & \multicolumn{3}{|c|}{ GAMG } & \multicolumn{3}{|c|}{ GA } & \multirow[b]{2}{*}{ T.B.E. (\%) } \\
\hline & T.E.A. (U) & $\begin{array}{l}\text { Enzyme activity } \\
\qquad(\mathrm{U} / \mathrm{mL})\end{array}$ & $\begin{array}{l}\text { Yield } \\
(\%)\end{array}$ & T.E.A. (U) & $\begin{array}{l}\text { Enzyme activity } \\
\qquad(\mathrm{U} / \mathrm{mL})\end{array}$ & $\begin{array}{l}\text { Yield } \\
\text { (\%) }\end{array}$ & \\
\hline 1 & 4825 & 193 & 12.6 & 4040 & 161.6 & 14.2 & 26.8 \\
\hline 2 & 3747 & 149.9 & 9.7 & 4225 & 169.2 & 14.9 & 24.6 \\
\hline 3 & 3482 & 139.3 & 9.1 & 4713 & 188.5 & 16.6 & 25.7 \\
\hline
\end{tabular}

The reaction mixture was incubated at various time intervals. T.E.A.: total enzyme activity, T.B.E.: total bioconversion efficiency. Values are the average of three independent experiments and the maximal mean deviation is $\pm 4 \%$. ANOVA test at $p \leq 0.001$ highly significant, $\leq 0.05$ significant. 
Table 3: Effect of substrate concentration on $\beta$ - glucuronidase activity

\begin{tabular}{cccccc}
\hline $\begin{array}{c}\text { Substrate } \\
\text { concentration } \\
(\mathrm{mg} / \mathrm{mL})\end{array}$ & GAMG & \multicolumn{2}{c}{$\mathrm{GA}$} & \multirow{2}{T}{$\begin{array}{c}\text { T.B.E } \\
(\%)\end{array}$} \\
\cline { 2 - 6 } & Enzyme activity $(\mathrm{U} / \mathrm{mL})$ & Yield $(\%)$ & Enzyme activity $(\mathrm{U} / \mathrm{mL})$ & Yield (\%) & \\
\hline 0.5 & 93.5 & 24.3 & 86.3 & 30.4 & 54.7 \\
1 & 196 & 25.5 & 134 & 23.6 & 49.1 \\
2 & 205 & 13.3 & 149 & 13.1 & 26.4 \\
3 & 184 & 8 & 140.6 & 8.2 & 16.2 \\
4 & 97.5 & 3.1 & 135.9 & 6 & 9.1 \\
\hline
\end{tabular}

The reaction mixture ( $1 \mathrm{~mL}$ of enzyme solution and $1 \mathrm{~mL}$ of different concentrations of $\mathrm{GL}$ in $1 \mathrm{M}$ Tris-maleate, $\mathrm{pH} 6)$ was incubated at $40{ }^{\circ} \mathrm{C}$ for $1 \mathrm{~h}$. Values are the average of three independent experiments and the maximal mean deviation is $\pm 4 \%$. ANOVA test at $p \leq$ 0.001 highly significant, $\leq 0.05$ significant.

Table 4: Effect of addition of different carbon sources on enzyme production

\begin{tabular}{lrrrrrr}
\hline Carbon source $(1 \mathrm{~g} \%)$ & Control & Glucose & Sucrose & Starch & Glycerol & Flour \\
\hline GAMG E.A. $(\mathrm{U} / \mathrm{mL})$ & 223 & 264 & 204 & 28 & 90 & 33 \\
GA E.A. $(\mathrm{U} / \mathrm{mL})$ & 107 & 119 & 155 & 77 & 132 & 65
\end{tabular}

A. terreus was cultivated on medium III supplemented with $1 \%$ solution of one of these carbon sources. The medium was inoculated with $5 \%, \mathrm{v} / \mathrm{v}$ inoculum and incubated at $150 \mathrm{rpm}$ and $27^{\circ} \mathrm{C}$ for $72 \mathrm{~h}$. Values of enzyme activity (E.A) are the average of three independent experiments and the maximal mean deviation is $\pm 5 \%$. ANOVA test at $p \leq 0.001$ highly significant, $\leq 0.05$ significant.

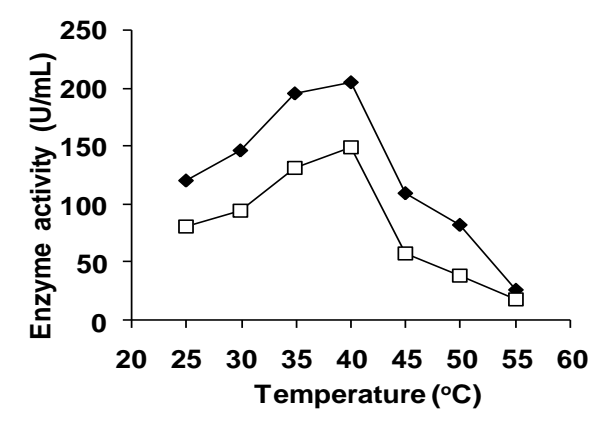

Figure 3: Effect of temperature on $\beta-D$ - glucoronidase activity. GAMG ( $\bullet$ ) and GA (口). The reaction mixture $(1 \mathrm{~mL}$ of enzyme solution and $1 \mathrm{~mL}$ of $0.2 \% \mathrm{GL}$ in $1 \mathrm{M}$ Tris-maleate, $\mathrm{pH} 6$ ) was incubated at different temperatures. Values are the average of three independent experiments and the maximal mean deviation is $\pm 6 \%$

May be $\beta$-D-glucuronidase gene from $A$. terreus was similar to lac operon. The $\beta$-D-glucuronidase gene had its own promoter to which RNA polymerase binds and initiates transcription. In the absence of an inducer (such as GL), $\beta$-D-glucuronidase gene was transcribed, producing repressor protein. This protein binded to the operator site and prevented transcription of the operon. In the presence of an inducer, the inducer binded to the repressor and changed its conformation, reducing its affinity for the operator. Thus, the repressor now dissociated and allowed RNA polymerase to transcribe

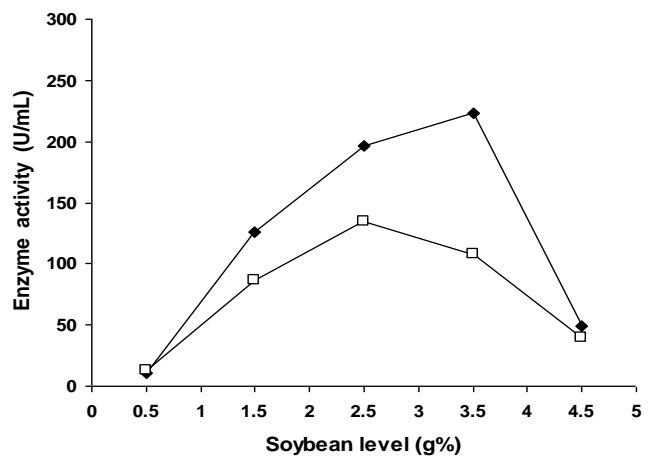

Figure 4: Effect of soybean on enzyme production. The amount of soybean in medium III was substituted by different concentrations. The medium was inoculated with $5 \%, \mathrm{v} / \mathrm{v}$ inoculum and shaked at $150 \mathrm{rpm}$ and $27{ }^{\circ} \mathrm{C}$ for $72 \mathrm{~h}$. Values of GAMG ( $\bullet)$ and GA ( $\square$ ) are the average of three independent experiments and the maximal mean deviation is $\pm 6 \%$

the operon. Then $\beta$-D-glucuronidase was expressed (Feng et al., 2006).

With regard to optimization of medium III constituents, different levels of soybean and corn steep liquor were used. Figure 4 indicates that $3.5 \mathrm{~g} \%$ soybean level maintained the maximum activity for GAMG production (205 $\mathrm{U} / \mathrm{mL}$ ), while that for GA production (161 $\mathrm{U} / \mathrm{mL}$ ) was recorded at $2.5 \mathrm{~g} \%$ soybean level. However, $2.5 \mathrm{~g} \%$ corn steep liquor was the optimal level for the production of both GAMG and GA (Figure 5). 
With regard to an additional carbon source, enzyme production medium was supplemented with $1 \%$ solution of one of the following five carbon sources: glycerol, glucose, sucrose, starch and wheat flour. Data illustrated in Table 4 show that addition of glucose afforded the highest GAMG production, while addition of glycerol led to the maximum GA production. The effect of different levels of glucose on the enzyme production was studied. Figure 6 shows that the low level of glucose $(0.5 \mathrm{~g} \%)$ supported the maximum GAMG production $(333.8 \mathrm{U} / \mathrm{mL})$, while increasing of glucose level over $1 \mathrm{~g} \%$ resulted in dramatic decrease in the enzyme activity. On the other hand, the optimum yield of GA was recorded using $1 \mathrm{~g} \%$ of glucose and there was a gradual decrease in the enzyme activity accompanied by increasing glucose concentration over the latter concentration. These results suggest that although glucose acts as inducer for cell growth it is an inhibitor for enzyme production, which starts after disappearance of glucose.

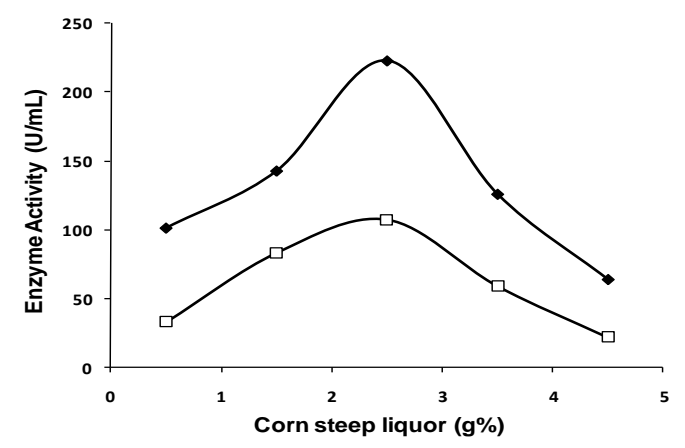

Figure 5: Effect of corn steep liquor on enzyme production

The amount of corn steep liquor in medium III was substituted by different concentrations. The medium was inoculated with $5 \%, \mathrm{v} / \mathrm{v}$ inoculum and shaked at $150 \mathrm{rpm}$ and $27^{\circ} \mathrm{C}$ for $72 \mathrm{~h}$. Values of GAMG $(\diamond)$ and $\mathrm{GA}(\square)$ are the average of three independent experiments and the maximal mean deviation is $\pm 6 \%$.

\section{Effect of $\mathrm{pH}$ and culture temperature on enzyme production}

A. terreus was cultivated on medium composed of soybean flour $3.5 \%$, corn steep liquor $2.5 \%$, glucose $0.5 \%$ and $\mathrm{CaCO}_{3}$ 0.5\% under different initial pHs between 4.0 and 0.9. The present investigation (data not shown) revealed that the highest enzyme activities for production of both GAMG and $\mathrm{GA}(333,123 \mathrm{U} / \mathrm{mL}$, respectively) were recorded at $\mathrm{pH} 6$. In agreement with the present results, Akao (1997) found that GL was hydrolyzed in the rat intestinal tract between $\mathrm{pH} 6$ and 7 . Also, Kuramoto et al. (1994) demonstrated that the maximum yield of GAMG was observed at $\mathrm{pH} 5.7$.

Concerning the effect of different incubation temperatures on the enzyme activity, the results (data not shown) showed that the temperature range from 27 to 30 ${ }^{\circ} \mathrm{C}$ was maintained high hydrolysis activity. The maximum enzyme activity for production of GAMG was obtained at temperature of $27^{\circ} \mathrm{C}$, while that for production of GA was recorded at $30^{\circ} \mathrm{C}$. So, the optimum culture temperature was set at $27^{\circ} \mathrm{C}$.

The influence of the inoculum size was studied by inoculating the enzyme production medium with different inoculum sizes ranging from 5 to $25 \%$, v/v (data not shown). It was demonstrated that the enzyme activities

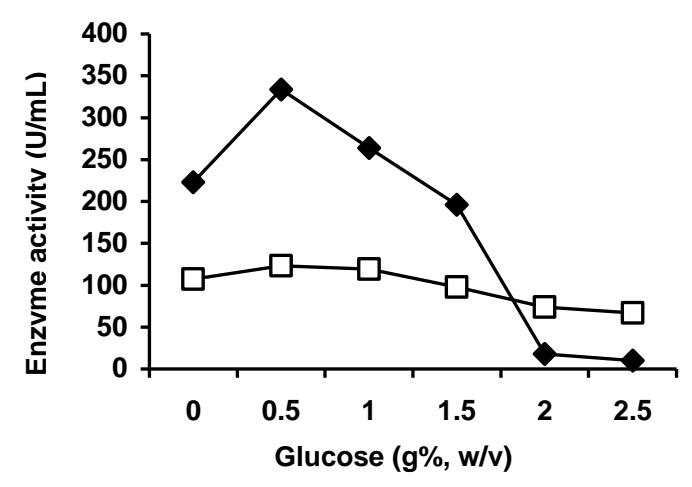

Figure 6: Effect of glucose level on enzyme production. The enzyme production medium (composed of soybean, 3.5 corn step liquor, 2.5; $\mathrm{CaCo}_{3}, 0.5$ $\mathrm{g} \%, \mathrm{w} / \mathrm{v} ; \mathrm{pH} 6)$ was supplemented with different glucose levels and inoculated with $5 \%, \mathrm{v} / \mathrm{v}$ inoculum. Then incubated at $150 \mathrm{rpm}$ and $27{ }^{\circ} \mathrm{C}$ for $72 \mathrm{~h}$. Values of GAMG $(\diamond)$ and GA ( $\square$ ) are the average of three independent experiments and the maximal mean deviation is $\pm 5 \%$

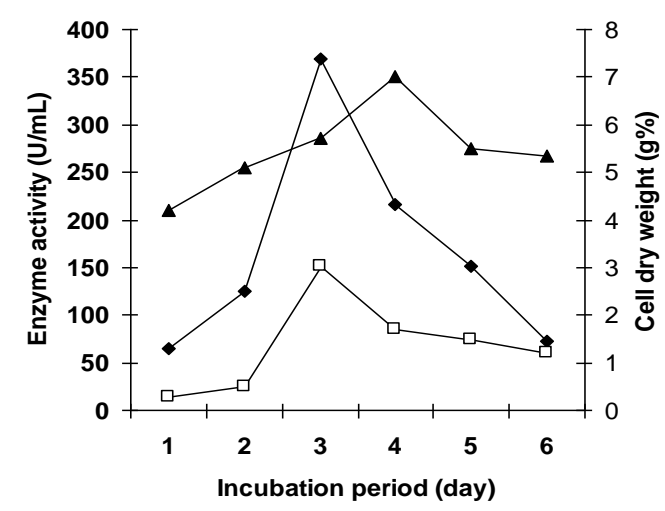

Figure 7: Course of cultivation of $A$. terrus. A. terrus was cultivated on the optimized enzyme production medium and the enzyme activities for GAMG $(\diamond)$ and GA ( $\square$ ) production, and cell dry weight $(\boldsymbol{\Delta})$ were determined at different time intervals. Values are the average of three independent experiments and the maximal mean deviation is $\pm 5 \%$ 
were positively responded to the increase of the inoculum size. A $15 \%$ inoculum was the optimum size for the highest enzyme activities $(396,152 \mathrm{U} / \mathrm{mL}$ for GAMG and $\mathrm{GA}$, respectively). Further increase in the inoculum size up to $25 \%$ was accompanied by the production of lower yields of GAMG and GA.

\section{Course of cultivation}

The course of cell growth and the hydrolysis activities are shown in Figure 7. The enzyme activities as well as the total bioconversion efficiencies were increased with the increase of the incubation period. The cells with the maximum enzyme activities of 396 and $152 \mathrm{U} / \mathrm{mL}$ for GAMG and GA, respectively (with yields of 51.5 and $26.8 \%$, respectively; and total bioconversion efficiency of $78.3 \%$ ), were obtained after cultivation for $72 \mathrm{~h}$. Moreover, the change trends of enzyme production and cell growth was roughly directly proportional. Consequently, the growth of $A$. terreus was partial coupled with enzyme production. Similar behavior was observed for $\beta-D$ glucuronidase from Penicillium sp. Li-3, which hydrolyzed GL to GAMG with maximum enzyme activity of 181.53 $\mathrm{U} / \mathrm{mL}$ (Feng et al., 2006). Moreover, Kuramoto et al. (1994) found that Cryptococcus magnus MG $27^{+}$ selectively hydrolyzed the terminal $\beta$-glucuronyl linkage of GL to give GAMG in a yield of $95 \%$.

It is noteworthy to denote that with cultivation of $A$. terreus under the above conditions, GAMG yield became about 2 times higher than GA yield and the cells bioconversion efficiency increased from 24.6 to $78.3 \%$.

More properties of $\beta$-D-glucuronidase production by $A$. terreus and trials for enzyme purification will be further studied in the future. Also, this biotechnological study could be applied for production of GAMG from licorice extract on an industrial scale.

\section{REFERENCES}

Akao, T. (1997). Localization of enzymes involved in metabolism of glycyrrhizin in contents of rat gastrointestinal tract. Biological and Pharmaceutical Bulletin 20(2), 122-126.

Akao, T. (2000). Competition in the metabolism of glycyrrhetic acid monoglucuronide by mixed Eubacterium sp. GLH and Ruminococcus sp. P01-3. Biological and Pharmaceutical Bulletin 23(2), 149154.

Akao, T. (2001). Effect of $\mathrm{pH}$ on metabolism of glycyrrhizin glycyrrhetic acid and glycyrrhetic acid monoglucuronide by collected human intestinal flora. Biological and Pharmaceutical Bulletin 24(10), 11081112.

Akao, T., Akao, T., Hattori, M., Namba, T. and Kobashi, K. (1992). Inhibitory effects of glycyrrhetic acid and its related compounds on 3 alpha-hydroxysteroid dehydrogenase of rat liver cytosol. Biological and Pharmaceutical Bulletin (Tokyo) 40(5), 1208-1210.

Akao, T., Akao, T., Hattori, M., Yamamoto, K. and Namba, T. (1991). Hydrolysis of glycyrrhizin to $18 \beta$ - glycyrrhetyl monoglucuronide by lysosomal $\beta-D$ glucuronidase of animal livers. Biochemical and Pharmacology 41, 1025-1029.

Amin, H. A. (2005). Studies on the bioconversion of glycyrrhizin. Ph.D. Thesis. Faculty of Science, Cairo University, Giza, Egypt.

El-Menoufy, H. A. (1988). Microbiological transformation of some natural products. Ph. D. Thesis. Faculty of Science, Cairo University, Giza, Egypt.

Feng, S., Li, C., Xu, X. and Wang, X. (2006). Screening strains for directed biosynthesis of $\beta$-D-monoglucuronide-glycyrrhizin and kinetics of enzyme production. Journal of Molecular Catalysis $B$ : Enzymatic 43(1-4), 63-67.

Ito, M., Sato, A., Hirabayashi, K., Tanabe, F., Shigeta, S., Baba, M., De, C. E., Nakashima, H. and Yamamoto, N. (1988). Mechanism of inhibitory effect of glycyrrhizin on replication of human immunodeficiency virus (HIV). Antiviral Research 10(6), 289-298.

Kim, D. H., Lee, S. W. and Han, M. J. (1999). Biotransformation of glycyrrhizin to $18 \beta$-glycyrrhetinic acid-3-O- $\beta$-D-glucuronide by Streptococcus LJ-22, a human intestinal bacterium. Biological and Pharmaceutical Bulletin 22(3), 320-322.

Kuramoto, T., Ito, Y., Oda, M. Tamura, Y. and Kitahata., S. (1994). Microbial production of glycyrrhetic acid-3-O-mono- $\beta-D-$ glucuronide from glycyrrhizin by Cryptococcus magnus MG-27. Bioscience Biotechnology and Biochemistry 58(3), 455-458.

Lu, D., Li, H., Dai, Y. and Quyang, P. (2006). Biocatalytic properties of a novel crude glycyrrhizin hydrolase from the liver of the domestic duck. Journal of Molecular Catalysis B: Enzymatic 43, 148-152.

Lu, D. Q., Zhang, S., Wang, J., Li, H. and Dai, Y. (2008). Adsorption separation of $3 \beta$-D-monoglucurony $1-18$ $\beta$-glycyrrhetinic from directional biotransformation products of glycyrrhizin. African Journal of Biotechnology 7(22), 3995-4003.

Mizutani, K., Kambara, T., Masuda, H., Tamura, Y., Ikeda, T., Tanaka, O., Tokuda, H., Nishino, H., Kozuka, M., Konoshima, T. and Takasaki, M. (1998). Glycyrrhetic acid monoglucuronide (MGGR): biological activities. International Congress Series 1157 (Towards Natural Medicine Research in the $21^{\text {st }}$ Century). pp. 225-235.

Muro, T., Kuramoto, T., Imoto, K. and Okada, S. (1986). Purification and some properties of glycyrrhizinic acid hydrolase from Aspergillus niger GRM3. Agricultural and Biological Chemistry 50(3), 687-692.

Ortega, N., Matose, M. P., Pilar, M. C. and Busto, M. D. (2009). Neutrase immobilization on alginateglutraldehyde beads by covalent attachment. Journal of Agricultural and Food Chemistry 57, 109-115.

Park, H. Y., Park, S. H., Yoon, H. K., Han, M. J. and Kim, D. H. (2004). Anti-allergic activity of 18 betaglycyrrhetinic acid-3-O-D-glucuronide. Archives of Pharmaceutical Research 27(1), 57-60. 
Sakano, K. and Ohshima, M. (1986a). Structures of conversion products formed from 18ß-glycyrhetinic acid by Streptomyces sp. G-20. Agricultural and Biological Chemistry 50(3), 763-766.

Sakano K. and Ohshima, M. (1986b). Microbial conversion of $18 \beta$-glycyrrhetinic acid and $22 \alpha$ hydroxy -18 $\beta$-glycyrrhetinic acid by Chainia antibiotica. Agricultural and Biological Chemistry 50(5), 1239-1245.

Sebald, W., Meupert, W. and Weiss, H. (1979). Preparation of Neurospora Crassa mitochondria. Methods in Enzymology 55, 144-148. 